\title{
Editorial vol 74(3) September 2021
}

B. N. Chakraborty ${ }^{1,2}$

C Indian Phytopathological Society 2021

Dear Readers,

The third issue, volume 74 of Indian Phytopathology for July-September 2021 is ready. In this issue there are thirty five articles including three review articles, nineteen research articles, nine short communications and four new reports.

In the first review article, Dr. Vinayaka Hegde has emphasized on Phytophthora diseases of arecanut in India and focused on prior findings, present status and future prospects. The second review article is based on M. S. Pavgi Memorial Award Lecture delivered by Dr. R. Viswanathan, wherein impact of yellow leaf disease in sugarcane and its successful disease management to sustain crop production has been highlighted. The third review article is based on B. B. Mundkur Memorial Award Lecture delivered by Dr Chirantan Chattopadhyay on "Plant pathology in the era of new education policy: challenges and opportunities".

Molecular identification and management of Peronospora viciae causing downy mildew on field pea pods and molecular characterization and development of SCAR marker for detection of Ascochyta rabiei infecting chickpea have been documented. Using ISSR, URP and SRAP markers diversity of indigenous and exotic Diaporthe species associated with various crops were assessed. Epidemics of chocolate spot disease of Vicia faba caused by Botrytis fabae in Ethiopia, genetics of resistance to rust and powdery mildew in Linum usitatissimum and fungal diseases in nursery seedlings of Tectona grandis have been illustrated. Cloning, characterization and expression analysis of resistant gene analogues for wilt in chickpea were done. Effect of seed borne fungi on seed health of native populations of Cuminum cyminum and seasonal impact on population dynamics of Phytophthora spp. and disease progression in mandarin have been

B. N. Chakraborty

bncnbu@gmail.com

Indian Phyopathological Society, New Delhi, India

2 Department of Biological Sciences, Aliah University, Kolkata, India reported. Profiling of monosporidial populations of Tilletia barclayana causing kernel smut of rice has been done.

Biocontrol potential of Trichoderma spp. against Fusarium spp., incitant of Pokkah boeng disease of sugarcane under in vitro conditions and biocontrol activity of Trichoderma harzianum, Bacillus subtilis and Pseudomonas fluorescens against Meloidogyne incognita, Fusarium oxysporum and Rhizoctonial solani have been demonstrated. Antagonistic potential of Baeuveria bassiana has also been worked out against Pythium myriotylum causing damping off of tomato. Soil amendments with Crotolaria juncea and Tithonia diversifolia and their effects on yield and quality of two indigenous vegetables grown in a nematode infested field and Caenorhabditis elegans as bait for isolating promising biocontrol fungi against Meloidogyne incognita from India have been reported. Using RAPD and ISSR markers citrus canker causing pathotypes in citrus trees were characterized. Effects of Pseudomonas putida and Rhizophagus irregularis alone and in combination on growth, chlorophyll, carotenoid content and disease complex of carrot have been presented. Molecular characterization of recombinant Bipartite begomovirus associated with mosaic and leaf curl disease of cucumber and muskmelon and natural mixed infections on Phalaenopsis species by groundnut bud necrosis orthotospovirus, cymbidium mosaic virus and odontoglossum ringspot virus have been documented.

Potential of different fungicides for management of red rot of sugarcane have been explored while potential endophytic Trichoderma spp. have been evaluated as a biocontrol agent against Ganoderma boniense. Decline in fungal communities of grapevine in grape growing regions of Iran and in vitro tolerance to antifungal glycoalkaloids and biofilm forming ability of antagonistic yeast (Meyerozyma guilliermondii) have been discussed. Regulation of antioxidant enzymes in rice by abscisic acid and salicylic acid under biotic stress caused by Fusarium fujikuroi have been presented. Germplasm of peach and nectarines against Taphrina deformans were screened and Puccinia rust spores were detected in the sugarcane field using foldscope. Induction of resistance in tomato against root knot nematode under salt 
stress condition using DL- $\beta$ - amino butyric acid and bacterial antagonists against Ganoderma lucidum the incitant of root rot of Indian Mesquite have been discussed.

New records on pathogenic association of Albifimbria terrestris with rice seeds, fruit rot of Cucurbita moschata caused by Choanephora cucurbitarum in Sri Lanka, Didymella americana cuasing leaf blight of lily and Momordica balsamina, a new natural host of begomovirus have been reported.

Authors, reviewers, editorial board members, executive council members of Indian Phytopathological Society and business manager who have put in lot of efforts to bring out timely publication of this issue are gratefully acknowledged.
Authors are requested to submit the best research/review articles to Indian Phytopathology to maintain its quality high standard.

Prof. B. N. Chakraborty

Chief Editor, Indian Phytopathology

Publisher's Note Springer Nature remains neutral with regard to jurisdictional claims in published maps and institutional affiliations. 